\title{
TARI SEMUT SEBAGAI MEDIA PENGEMBANGAN KARAKTER BAGI SISWA SEKOLAH DASAR
}

\begin{abstract}
Hartini*
Abstract

A means of empowering students' self-potentials is through art performance. By so doing they may get first-hand experience, knowledge, skills, creative thinking, and sense of beauty. Their sense of arts guides them to do their works creatively, innovatively and aesthetically. An art performance which can be taught to them is dance. It helps them grow up and possess an awareness of multiculture both locally and globally which in its turn creates actions for respect, tolerance and harmony amidst the multi-cultural society. The sort of dance taught could be those which do not require pains-taking movements, while the themes could be about plays, daily activities, or animals. Semut (ant) dance is an example. Through practicing it, they not only have fun but also learn how to cooperate. Accordingly, it can serve as a medium to get them develop their characters through good deeds therein. Among the characters they can learn are: (1) respect and polite; (2) cooperation (gotong-royong); and (3) adaptation.
\end{abstract}

Key words: Semut Dance, Students' Character Development

\begin{abstract}
Abstrak
Salah satu bentuk pemberdayaan potensi diri siswa dapat diajarkan melalui kegiatan seni. Melalui seni siswa memperoleh berbagai pengalaman, pengetahuan, keterampilan, dan latihan berpikir kreatif serta peka akan keindahan. Dengan kemampuan rasa seni, siswa akan senantiasa mengerjakan pekerjaan dengan kreatif, inovatif, dan estetis. Salah satu contoh cabang seni yang dapat diajarkan di sekolah adalah seni tari. Seni tari dapat memberikan kesempatan pada anak untuk tumbuh dan berkembangnya sehingga akan memiliki kesadaran terhadap keragaman budaya baik lokal maupun secara global sebagai pembentukan sikap menghargai, toleran, dan hidup rukun dalam masyarakat dan budaya yang beraneka ragam. Tarian yang diajarkan untuk siswa sekolah dasar biasanya gerakan tidak terlalu rumit, dan gerakannya bertema tentang permainan, kegiatan sehari-hari, dan bertema tentang binatang. Salah satunya tarian semut, melalui tari semut, siswa tidak hanya memperoleh kesenangan saja, akan tetapi mereka dapat merasakan betapa pentingnya kerjasama dan kekompakan. Maka dari itu tari semut dapat dijadikan sebagai media pembelajaran karakter karena didalamnya terkandung nilai-nilai
\end{abstract}

* Hartini adalah Dosen Prodi PGSD FIP IKIP PGRI MADIUN 
kepribadian yang baik. Adapun nilai-nilai yang dapat dikembangkan meliputi: (1) hormat dan santun; (2) kerjasama / gotong royong; dan

(3) beradaptasi atau dapat menyesuaikan diri.

Kata kunci: Tari Semut, Pengembangan Karakter Siswa

\section{A. PENDAHULUAN}

Pendidikan karakter dapat dikatakan sebagai pengajaran moral dan akhlak yang bertujuan untuk membentuk pribadi menjadi baik. Melalui pendidikan karakter di sekolah, tentunya dapat membantu peserta didik dalam memahami nilai-nilai perilaku manusia yang berhubungan dengan Tuhan Yang Maha Esa, diri sendiri, sesama manusia, lingkungan, dan kebangsaan. Kemudian nilai-nilai tersebut dapat terwujud dalam pikiran, sikap, perasaan, perkataan, dan perbuatan berdasarkan norma-norma agama, hukum, tata krama, budaya, dan adat istiadat. Menurut Albertus karakter diasosiasikan dengan temperamen yang memberinya sebuah definisi yang menekankan unsur psikososial yang dikaitkan dengan pendidikan dan konteks lingkungan (Asmani, 2012: 28). Karakter juga dipahami dari sudut pandang behavioral yang menekankan unsur somato-psikis yang dimiliki oleh individu sejak lahir. Disini, karakter dianggap sama dengan kepribadian. Kepribadian dianggap sebagai ciri atau karakteristik / gaya atau sifat khas dari seseorang, yang bersumber dari bentukan-bentukan yang diterima dari lingkungan, misalnya pengaruh keluarga pada masa kecil dan bawaan seseorang sejak lahir.

Terkait dengan penyataan tersebut, dapat dikatakan bahwa seseorang yang berkepribadian / berkarakter baik, dapat dinilai dari sifat, perilaku, dan kebiasaan yang dilakukan dalam segala perbuatannya. Kepribadian dapat terbentuk dari lingkungan sekitar yang mempengaruhinya. Empat jenis karakter yang dikenal dan dilaksanakan dalam proses pendidikan, yaitu: (1) pendidikan berbasis nilai religius, yang merupakan kebenaran wahyu Tuhan; (2) pendidikan nilai karakter berbasis nilai budaya, antara lain menyangkut tentang budi pekerti, Pancasila, apresiasi sastra, serta keteladanan tokoh-tokoh sejarah dan para pemimpin bangsa; (3) pendidikan karakter berbasis lingkungan; dan (4) pendidikan karakter berbasis potensi diri, yaitu sikap pribadi, hasil proses kesadaran pemberdayaan potensi diri yang diarahkan untuk meningkatkan kualitas pendidikan.

Salah satu bentuk pemberdayaan potensi diri dapat diajarkan melalui kegiatan seni. Melalui seni siswa memperoleh berbagai pengalaman, pengetahuan, keterampilan dan latihan berpikir kreatif serta peka akan keindahan. Dengan kemampuan rasa seni, siswa akan senantiasa mengerjakan pekerjaan dengan kreatif, inovatif, dan estetis. Salah satu contoh cabang seni yang dapat diajarkan adalah seni tari. Seni tari dapat memberikan kesempatan pada anak untuk tumbuh dan berkembangnya sehingga akan memiliki kesadaran terhadap keragaman budaya baik lokal maupun secara global sebagai pembentukan sikap menghargai, toleran, dan hidup rukun dalam masyarakat dan budaya yang beraneka ragam.

Jazuli (2008: 16-17) menjelaskan bahwa makna pendidikan seni adalah pemberian pengalaman estetik (aesthetic experience) kepada siswa. Pengalaman estetik adalah pengalaman menghayati nilai keindahan, bagaimanapun keindahan itu dimaknai. Pemberian pengalaman estetik melalui dua kegiatan yang saling berkaitan, yakni apresiasi dan kreasi (appreciation) dan kreasi (creation). 
Didalam kegiatan apresiasi dan kreasi terkandung nilai ekspresi sebagai bentuk ungkapan yang bermakna. Dengan pendidikan seni melalui pengalam estetik, siswa diharapkan dapat menginternalisasi (meresapi, mengakarkan) nilai-nilai estetik yang berfungsi untuk melatih kepekaan rasa, kecerdasan intelektual, dan mengembangkan imajinasinya. Oleh karena itu, bahwa didalam pendidikan seni tidak melibatkan peran pikiran, menafsirkan kecerdasan intelektual, bahkan tidak melibatkan logika. Suatu pengalaman estetik tidak mungkin bisa dicapai tanpa melibatkan olah rasa (emosi, estetika), olah cipta (pikir, logika), dan olah raga (fisik, kinestika terutama untuk seni tari).

Seni tari memiliki peran dalam pembentukan pribadi siswa yang harmonis. Pemberian pengalaman dalam seni (tari), menjadi fungsional untuk mengembangkan berbagai kemampuan yang mempengaruhi sikap mental siswa dalam peradapan yang lebih manusiawi. Pekerti (2002: 165) mengemukakan bahwa karakteristik gerak fisik anak sekolah adalah bersifat sederhana, biasanya bersifat maknawi dan bertema binatang, artinya tiap gerak mengandung tema tertentu, gerak anak menirukan gerak keseharian orang tua dan juga orang yang berada disekitarnya, dan anak juga menirukan gerak binatang. Salah satu contoh tari bertema binatang adalah tari semut. Melalui tarian ini, anak-anak dapat dilatih mengolah kepekaan rasa dalam menyeimbangkan gerak dan iringan musik. Selain itu tari semut dijadikan sebagai media pembentukan karakter positif bagi anakanak.

Prinsip-prinsip pendidikan karakter menurut Asmani (2012: 56-57) didasarkan pada prinsip, yaitu: (1) mempromosikan nilai-nilai dasar etika sebagai basis karakter; (2) mengidentifikasi karakter secara komprehensif supaya mencakup pemikiran, perasaan, dan perilaku; (3) menggunakan pendekatan yang tajam, proaktif dan efektif untuk membangun karakter; dan (4) menciptakan komunitas sekolah yang memiliki kepedulian; (5) memberi kesempatan kepada peserta didik untuk menunjukkan perilaku yang baik; (6) memiliki cakupan terhadap kurikulum yang bermakna dan menantang yang menghargai semua peserta didik, membangun karakter mereka, dan membantu mereka untuk sukses; (7) mengusahakan tumbuhnya motivasi diri pada peserta didik; (8) memfungsikan seluruh staf sekolah sebagai komunitas moral yang berbagi tanggung jawab untuk pendidikan karakter dan setia pada nilai dasar yang sama; (9) adanya pembagian kepemimpinan moral dan dukungan luas dalam membangun inisiatif pendidikan karakter; (10) memfungsikan keluarga dan anggota masyarakat sebagai mitra dalam usaha membangun karakter; dan (11) mengevaluasi karakter sekolah, fungsi staf sekolah sebagai guru-guru karakter dan manifestasi karakter positif dalam kehidupan peserta didik.

Secara langsung seni tari bagi anak dapat dijadikan sebagai media ekspresi yang isinya mengungkapkan perasaan. Sebagai contoh tari yang menggambarkan rasa gembira. Tari dapat dijadikan pula sebagai media komunikasi yang biasanya berisi pesan/ajakan, dan tari sebagai media bermain menirukan tingkah laku binatang, tumbuhan dan benda alam lain yang mengandung sifat bermain. Selain itu tari dapat dijadikan sebagai media pengembang bakat/kemampuan yang dimiliki anak. Melalui kemampuan yang tampak, maka bakat tersebut dapat dikembangkan melalui pelatihan dan diikutsertakan dalam berbagai kegiatan seni tari. Sebagai contoh aktif mengikuti perlombaan maupun festival. Dengan begitu anak-anak mendapatkan pengalaman dalam mengembangkan bakatnya. Selain itu 
seni tari diajarkan supaya anak memiliki persepsi dan pengetahuan, serta berkembang dalam beradaptasi. Melalui kegiatan menari, anak memiliki kemampuan mengekspresikan diri melalui gerak tari, sebab akan terjadi perpaduan antara unsur logika, etika, dan estetika. Dengan demikian toleransi anak dapat tumbuh, dan dapat menghargai perbedaan terhadap orang lain.

\section{B. PEMBAHASAN}

\section{Tari Semut sebagi Media Pengembangan Karakter}

Djelantik (2004: 23) mengemukakan bahwa gerak merupakan unsur penunjang yang paling besar peranannya dalam seni tari. Dengan gerak terjadinya perubahan tempat, perubahan posisi dari benda, tubuh penari atau sebagian dari tubuh. Semua gerak melibatkan ruang dan waktu. Dalam ruang sesuatu yang bergerak menempuh jarak tertentu, dan jarak dalam waktu tertentu ditentukan oleh kecepatan gerak. Semua gerak memerlukan tenaga, untuk gerak tubuh penari diambil tenaga dari sang penari sendiri. Sang penari harus selalu siap mengeluarkan tenaga dan energi yang sesuai. Terkait hal itu, maka seseorang yang akan menampilkan tarian hendaknya menjaga stamina tubuh, sebab bila stamina menurun maka akan mempengaruhi kekuatan dan keluwesan gerak pula.

Ritme atau irama dalam satu karya seni, merupakan hal yang menunjukkan kehadiran sesuatu yang terjadi berulang-ulang secara teratur. Keteraturan ini bisa mengenai jaraknya yang sama, seperti contoh misalnya gerak dalam seni tari. Tari bagi anak dapat dijadikan sebagai media untuk mengungkapakan ide, gagasan, pengetahuan, wawasan, pengalaman, dan kejadian-kejadian yang disimbolkan melalui gerak. Gerak dalam tari semut cenderung diulang ulang, dan tidak terlalu rumit bila diajarkan bagi siswa sekolah dasar. Gerakannya menirukan gerak-gerik binatang semut. Kostum yang dikenakanpun bersifat lucu dan menyenangkan. Melalui tarian ini, siswa tidak hanya memperoleh kesenangan saja, akan tetapi mereka dapat merasakan betapa pentingnya kerjasama dan kekompakan.

Ritme mempunyai peranan yang besar dalam seni musik, seni karawitan, dan seni tari. Ritme yang konstan (terus menerus) dan tidak berobah, rasa jemuh itu berbahaya karena bisa mengurangi daya tarik dan mutu estetikanya. Daya tarik itu bisa ditambah dengan membuat karyanya lebih bervariasi. Hal ini dapat dicapai dengan perobahan-perobahan ritmenya misalnya kecepatan ritme bisa diganti-ganti secara teratur, ritme itu bisa diberi modus yang lain, atau jenis instrumen yang membuat atau menonjolkan ritme itu digilir. Banyak sekali-kali cara-cara untuk membuat variasi dalam ritme (Djelantik, 2004:40). Hal ini dipertegas oleh Suyatno yang mengemukakan sembilan pilar karakter, yakni:
a. Cinta Tuhan dan segenap ciptaan-Nya;
b. Kemandirian dan tanggung jawab;
c. Kejujuran dan amanah;
d. Hormat dan santun;
e. Dermawan, suka tolong-menolong, dan gotong royong atau kerjasama;
f. Percaya diri dan pekerja keras;
g. Kepemimpinan dan keadilan;
h. Baik dan rendah hati;
i. Toleransi, kedamaian, dan kesantunan. 


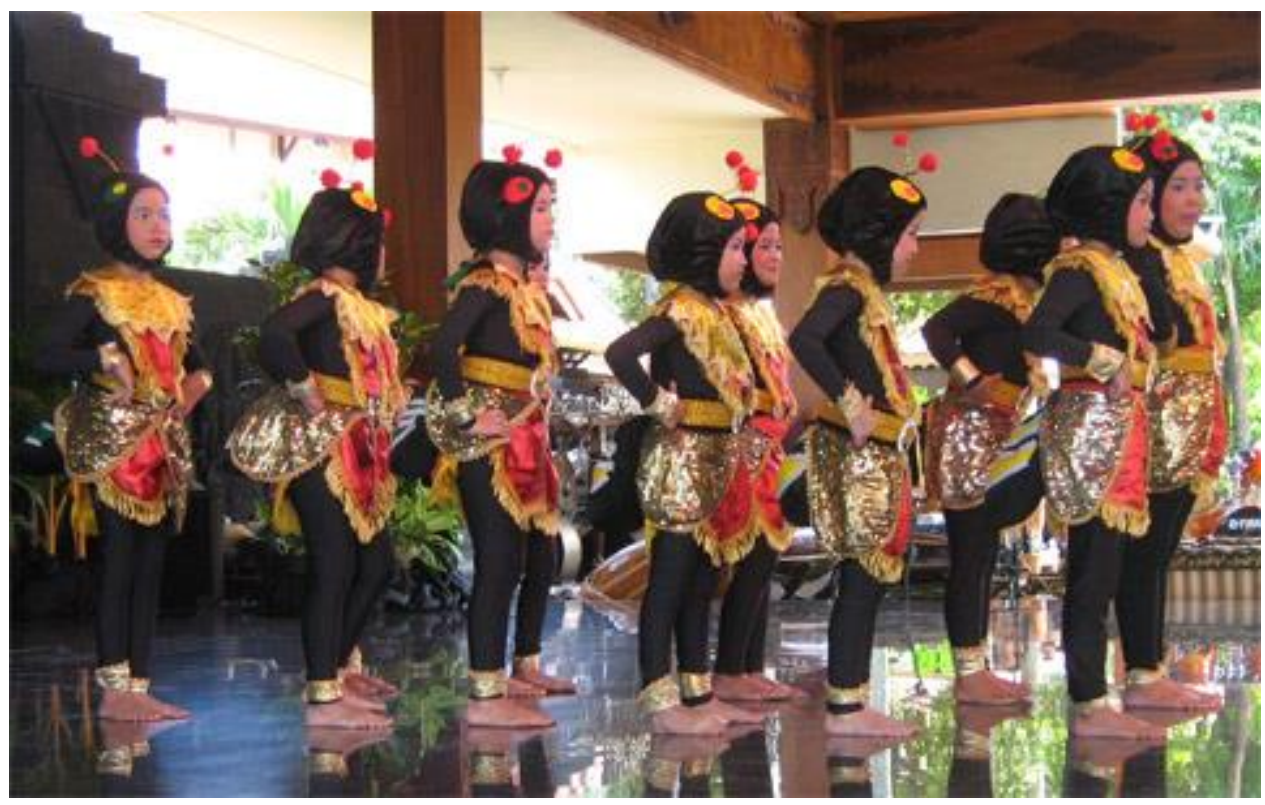

Gambar 1 Tari Semut (Sumber: http://paxhigh.com)

Berdasarkan uraian di atas, nilai karakter yang tertuang dalam Tari Semut (diilustrasikan pada Gambar 2), yakni:

a. Hormat dan santun, hal ini digambarkan bahwa binatang semut saat bertemu selalu menyapa, bersalaman, dan bersabar antri;

b. Kerjasama / gotong royong, hal ini digambarkan bahwa binatang semut selalu bergerombol / bersama-sama dalam menanggung beban yang dibawanya;

c. Beradaptasi atau dapat menyesuaikan diri, hal ini digambarkan bahwa binatang semut dapat datang kapan saja terhadap makanan yang manis dan enak, tetapi dapat datang juga pada makanan atau sesuatu yang berbau tidak sedap.

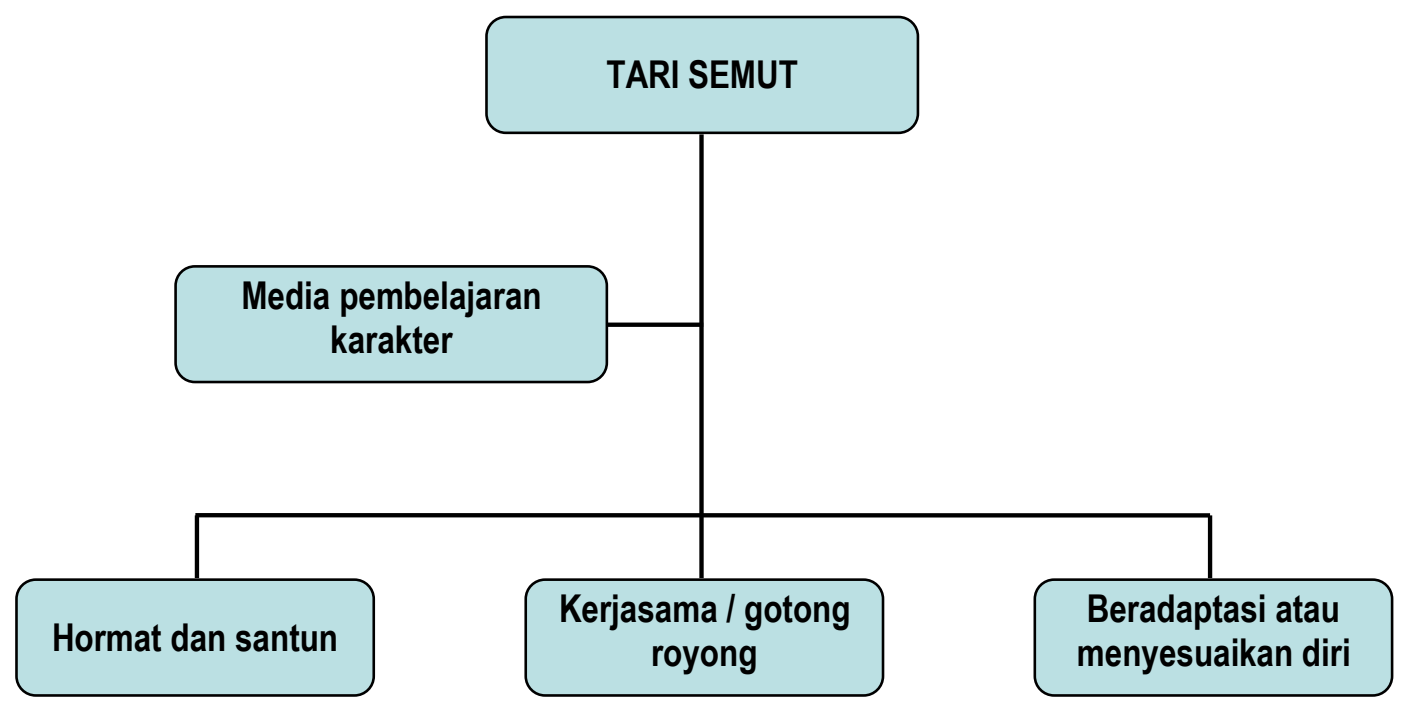

Gambar 2 Sikap yang dapat Dikembangkan melalui Tari Semut 


\section{Peran Media dalam Pembelajaran}

Belajar adalah suatu proses yang kompleks, dan belajar dapat terjadi kapan saja dan dimana saja. Dalam prosesnya terjadi perubahan tingkah laku yang disebabkan terjadinya perubahan pada tingkat pengetahuan, keterampilan, atau sikapnya. Arsyad (2011: 3) mengemukakan bahwa media berasal dari bahasa Latin medius yang secara harafiah berarti tengah, perantara, atau pengantar. Sedangkan Gerlcah \& Ely (1971) menyatakan bahwa media apabila dipahami secara garis besar adalah manusia, materi, atau kejadian yang membangun kondisi yang membuat siswa mampu memperoleh pengetahuan, keterampilan, atau sikap. Dalam pengertian ini, guru, buku teks, dan lingkungan sekolah merupakan media. Secara lebih khusus, pengertian media dalam proses belajar mengajar cenderung diartiakan sebagai alat-alat grafis, fotografis, atau elektonis untuk menangkap, memproses, dan menyusun kembali informasi visual atau verbal.

Media pembelajaran tentunya melibatkan siswa untuk membentuk aktifitas yang nyata sehingga pembelajaran dapat terjadi. Materi dirancang secara sistematis dan psikologis. Disamping menyenangkan, media pembelajaran dapat memberikan pengalaman yang menyenangkan dan memenuhi kebutuhan setiap siswa. Hamalik menjelaskan bahwa pemakaian media pembelajaran dalam proses belajar mengajar dapat membangkitkan keinginan dan minat yang baru, membangkitkan motivasi dan rangsangan kegiatan belajar, dan bahkan membawa pengaruh-pengaruh psikologis terhadap siswa (Arsyad, 2011:15). Penggunaan media pembelajaran pada tahap orientasi pembelajaran akan sangat membantu keefektifan proses pembelajaran dan penyampaian pesan, dan isi pelajaran saat itu. Selain membangkitkan motivasi dan minat siswa, media pembelajaran juga dapat membantu siswa meningkatkan pemahaman, menyajikan data dengan menarik dan terpercaya.

Terkait dalam seni tari, Hartono (2012: 64) berpendapat bahwa tari sebagai media pembelajaran diberikan sebagai alat mencapai tujuan pembelajaran. Hal yang utama dalam hal ini lebih ditekankan pada tujuan pembelajarannya bukan pada penguasaan tari itu sendiri. Bentuk kegiatan berupa aktivitas fisik dan cita rasa keindahan, yang tertuang dalam kegiatan berekspresi, berekplorasi, berkreasi dan berapresiasi melalui tari. Dari kegiatan tersebut akan diperoleh pengetahuan dan pemahaman sesuatu hal yang menjadi tujuan pembelajaran. Namun, walaupun penguasaan tari tidak menjadi tuntutan, pada akhir pembelajaran, pada umumnya anak-anak menunjukkan kemampua yang baik dalam berapresiasi tentang tari, keterampilan, dan merasakan sentuhan keindahan dalam tari disamping tujuan pembelarannya tercapai.

Jadi dalam hal ini, tari sebagai media pembelajaran. Keterampilan, kepekaan irama, dan ekspresi bukan menjadi tujuan utama melainkan pembelajaran. Melalui kegiatan berseni tari, disamping anak mendapatkan pengetahuan lain yang telah ditetapkan sebagai pencapaian tujuan pembelajaran, anak juga dapat melakukan gerak tari dan merasakan keindahannya. Sudjana \& Rivai mengemukakan manfaat media pembelajaran dalam proses belajar siswa (Arsyad, 2011: 24-25), yaitu:

a. Pembelajaran akan lebih menarik perhatian siswa sehingga dapat menumbuhkan motivasi belajar; 
b. Bahan pembelajaran akan lebih jelas maknanya sehingga dapat lebih dipahami oleh siswa dan memungkinkannya menguasai dan mencapai tujuan pembelajaran;

c. Metode mengajar akan lebih bervariasi, tidak semata-mata komunikasi verbal melalui penuturan kata-kata oleh guru, sehingga siswa tidak bosan dan guru tidak kehabisan tenaga, apalagi kalau guru mengajar pada setiap jam pelajaran;

b. Siswa dapat lebih banyak melakukan kegiatan belajar sebab tidak hanya mendengarkan uraian guru, tetapi juga aktivitas lain seperti mengamati, melakukan, mendemontrasikan, dan memerankan.

Sedangkan Encyclopedia of educational Research merincikan manfaat media pendidikan (Hamalik, 1994: 15), yakni:

a. Meletakkan dasar-dasar konkret untuk berpikir, oleh karena itu mengurangi verbalisme;

b. Memperbesar perhatian siswa;

c. Meletakkan dasar-dasar yang penting untuk perkembangan belajar, oleh karena itu membuat pelajaran lebih mantap;

d. Memberikan pengalaman nyata yang dapat menumbuhkan kegiatan berusaha sendiri di kalangan siswa;

e. Menumbuhkan pemikiran yang teratur dan kontinyu, terutama melalui gambar hidup;

f. Membantu tumbuhnya pengertian yang dapat membantu perkembangan berbahasa;

g. Memberikan pengalaman yang tidak mudah diperoleh dengan cara lain, dan membantu efisiensi dan keragaman yang lebih banyak dalam belajar;

Berdasarkan uraiaun di atas, dapat disimpulkan bahwa media dapat membantu siswa dalam memeroleh pengalaman dan pengetahuan dengan cara mengamati, praktik langsung / memperagakan, memerankan, dan mendemontrasikan. Dengan hal ini siswa tidak merasa bosan dan pasif sebagai pendengar saja, akan tetapi lambat laun akan tumbuh pikiran yang kreatif dan inovatif.

\section{Pengembangan Karakter Siswa Sekolah Dasar}

Anak usia sekolah dasar mempunyai kecenderungan untuk mengumpulkan macam-macam benda seperti perangko, kartu-kartu, manik warna-warni, gambargambar dan lain-lain. Mereka juga mulai memandang semua peristiwa dengan obyektif. Kartono (1995: 138) berpendapat bahwa minat anak pada periode tersebut terutama sekali tercurah pada segala sesuatu yang dinamis bergerak. Anak pada usia ini sangat aktif dan dinamis. Segala sesuatu yang aktif dan bergerak akan sangat menarik minat-perhatian anak. Lagi pula minatnya banyak tertuju pada macam-macam aktivitas. Semakin banyak dia berbuat, makin bergunalah aktivitas tersebut bagi proses pengembangan kepribadiannya. Ingatan anak pada usia 8 s.d. 12 tahun ini mencapai intensitas paling besar, dan paling kuat. Daya menghafal dan daya memorisasi (dengan sengaja memasukkan dan meletakkan pengetahuan dalam ingatan) adalah paling kuat. Dan anak mampu memuat jumlah materi ingatan paling banyak. 
Pikiran anak usia sekolah dasar dalam keadaan normal, berkembang secara berangsur-angsur dan secara tenang. Disamping keluarga, sekolah memberikan pengaruh yang sistematis terhadap pembentukan akal budi-anak. Pengetahuannya bertambah dan banyak keterampilan mulai dikuasai. Maka dalam periode masa anak sekolah dasar banyak hal yang ingin diketahui dan diteliti. Selain itu potensi diri yang tampak pada anak sekolah dasar dapat diasah dan dikembangkan dengan maksimal. Dengan mengasah dan mengembangkan potensi diri siswa, akan terbentuk pula karakter/kepribadian yang lebih baik. Hal ini dipertegas oleh Asmani (2012: 65-66) yang menyatakan pendidikan karakter berbasis potensi diri memiliki beberapa kelebihan, yaitu:

a. Proses kegiatan pendidikan karakter berbasis potensi dilakukan dengan segala daya upaya. Artinya, dalam proses pendidikan karakter berbasis potensi diri, guru tidak hanya berperan sebagai pengajar yang menyampaikan materi pengajaran, tetapi ia juga bertindak sebagai inspirator, inisiator, fasilitator, mediator, supervisor, evaluator, teman (friend) sekaligus pembimbing (counselor), lebih matang (nurturer), dan sepenuh hati dengan cinta dan kasih sayang (devoted);

b. Anak didik mampu mengatasi diri. Artinya, ia mampu bersikap mandiri, mampu mengatasi segala problem keuangan, perkuliahan, kesehatan, pribadi (emosi), keluarga, pengisian waktu senggang, agama dan akhlak, perkembangan pribadi dan sosial, memilih pekerjaan, serta persiapan untuk keluarga melalui kebebasan dan penalaran;

c. Kebebasan merupakan suatu kondisi dan situasi merdeka. Tidak ada tekanan dari siapapun dan dari pihak manapun. Bebas menyatakan pendapat, menentukan pilihan, berpikir, melakukan aktivitas, berkreasi, dan berkeyakinan bermanfaat bagi diri sendiri, orang lain, masyarakat, bangsa dan negara, serta tidak merugikan siapapun;

d. Penalaran. Ini merupakan kemampuan berpikir yang benar dan teruji kebenarannya, yaitu kemampuan berpikir logis dan analitis. Berpikir logis merupakan kemampuan menggeneralisasikan pernyataan-pernyataan khusus (logika induktif melalui pengamatan empiris) atau menyimpulkan pernyataan umum atau khusus (logika deduktif melalui cara berpikir rasional);

e. Segala potensi anak didik. Artinya, setiap anak didik bersifat unikl. Mereka memiliki potensi terpendam. Dalam proses pendidikan karakter, semua potensi yang dimiliki anak didik digali dan diberdayakan untuk bekal hidup mereka. Potensi diri dimiliki oleh setiap manusia normal. Potensi diri sangat banyak, yang antara lain etos belajar, idealisme pendidikan, mind mapping (penataan informasi agar mudah diakses), multiple intellegence (kecerdasan ganda), public speaking (keterampilan berbicara di depan umum), effective thinking (pola bepikir efektif), editing (penyuntingan karangan), brainstorming, pelaksanaan model pembelajaran kooperatif tipe komprehensif (MPKTK), sinergi pemberdayaan potensi mahasiwa, lesson study (pengamatan pembelajaran di kelas), serta information and communication technology.

\section{PENUTUP}

Seni tari memiliki peran dalam pembentukan pribadi siswa yang harmonis.

Pemberian pengalaman dalam seni tari, menjadi fungsional untuk 
mengembangkan berbagai kemampuan yang memengaruhi sikap mental siswa dalam peradapan yang lebih manusiawi. Selain itu seni tari diajarkan supaya anak memiliki persepsi dan pengetahuan, serta berkembang dalam beradaptasi. Melalui kegiatan menari, anak memiliki kemampuan mengekspresikan diri melalui gerak tari, sebab akan terjadi perpaduan antara unsur logika, etika, dan estetika. Dengan demikian toleransi anak dapat tumbuh, dan dapat menghargai perbedaan terhadap orang lain. Tari semut dapat dijadikan sebagai media pembelajaran karakter bagi siswa di Sekolah Dasar karena didalamnya terkandung nilai-nilai yang dapat diajarkan. Adapun beberapa nilai karakter yang tertuang dalam tari semut, yakni: (1) hormat dan santun; (2) kerjasama; dan (3) dapat beradaptasi.

Hormat dan santun, hal ini digambarkan bahwa binatang semut saat bertemu selalu menyapa, bersalaman,dan bersabar antri. Dengan begitu siswa akan mengerti dan memahami artinya menghormati dan menghargai orang lain. Kerjasama/gotong royong, hal ini digambarkan bahwa binatang semut selalu bergerombol/bersama-sama dalam menanggung beban yang dibawanya. Melalui gambaran ini, siswa akan mengerti dan memahami artinya kerjasama dan gotongroyong. Segala beban, permasalahan, pekerjaan, apabila ditanggung bersamasama akan terasa lebih ringan. Dari sinilah siswa akan memahami bahwa manusia hidup tidak dapat hidup sendiri. Manusia hidup membutuhkan orang lain dan ada orang lain disekitarnya. Beradaptasi atau dapat menyesuaikan diri, hal ini digambarkan bahwa binatang semut dapat datang kapan saja terhadap makanan yang manis dan enak, tetapi dapat datang juga pada makanan atau sesuatu yang berbau tidak sedap. Melalui gambaran ini, siswa akan mengerti dan memahami bahwa dimanapun ia berada hendaknya dapat menyesuaikan diri. Pada saat suka ia dapat senang, akan tetapi di saat duka ia juga mau merasakannya. Apabila berteman dengan sesama tidak hanya dekat/berkenan pada saat suka/senangnya saja akan tetapi pada saat duka/kesusahan ia juga dapat merasakannya. 


\section{DAFTAR RUJUKAN}

Arsyad, A. 2011. Media Pembelajaran. Jakarta: PT Rajagrafindo Persada.

Asmani, M. J. 2012. Pendidikan Karakter di Sekolah. Yogyakarta: DIVA Press.

Djelantik, M. A. A. 2004. Estetika Sebuah Pengantar. Bandung: Masyarakat Seni Pertunjukan Indonesia.

Hartono. 2012. Pembelajaran Tari Anak Usia Dini. Semarang: Unnes Press.

Jazuli, M. 2008. Paradigma Kontekstual Pendidikan Seni. Surabaya: Unesa University Press.

Kartono, K. 1995. Psikologi Anak, Psikologi Perkembangan. Bandung: Mandar Maju.

Tari Semut (Online). (http://paxhigh.com/spaw/images/artperformance_sd.jpg, diakses 23 Juli 2013). 